\title{
Exogenous Application of Selected Antioxidants and Phyto Development Directors Influenced the Development, Output and Biochemical Attributes of'Tomato (Lycopersicum esculentum Mill.)
}

\author{
Safina Naz ${ }^{1}$, Syed Atif Hasan Naqvi ${ }^{2 *}$, Bushra Siddique ${ }^{3}$, Muhammad Asif Zulfiqar ${ }^{4}$ and Abdur Rehman ${ }^{5}$
}

${ }^{1}$ Department of Horticulture, Bahauddin Zakariya University, Multan, Pakistan; ${ }^{2}$ Department of Plant Pathology, Bahauddin Zakariya University, Multan, Pakistan; ${ }^{3}$ Department of Entomology, University College of Agriculture and Environmental Sciences, Islamia University of Bahawalpur, Pakistan; ${ }^{4}$ PARC, Research and Training Station, Bahauddin Zakariya University, Multan; ${ }^{5}$ Plant Protection Department, College of Food and Agriculture Sciences, King Saud University, Riyadh, Kingdom of Saudi Arabia.

\begin{abstract}
This study investigated the comparative efficacy of phyto development director i.e. N.A.A.GA, 2, 4-Dichlorophenoxyacetic acid and antioxidants i.e. Ascorbic acid and 2-hydroxybenzoic acid on development, fruit bearing, output along with biochemical attributes of Lycopersicum esculentum fruits during 2014 and 2015. Foliar spray of $\mathrm{GA}_{3}(100 \mathrm{ppm})$ and 2-hydroxybenzoic acid (200 parts/million and 100 parts/million) give rise to significantly taller plants and greater leaf area while, shorter plants and lower leaf area was recorded in control. Greater leaf number per plant was obtained with application of $\mathrm{GA}_{3}(100 \mathrm{ppm})$. This was followed by salicylic acid (200 ppm). Leaf number was significantly lesser in the plants grown in control. Significantly greater fruit count /plant, length of fruit including sole fruit freshness and dry mass were recorded with $\mathrm{GA}_{3}(100 \mathrm{parts} / \mathrm{million})$ and salicylic acid $(200 \mathrm{ppm})$ provision and lower values for these parameters were recorded with control. Fruit weight for single plant and output of fruit per hectare successfully recorded from plants grown containing foliar spray of Gibberellic acid at 100 parts/million while lower values were attained with control. Spray of salicylic acid (200 ppm), GA $3(100 \mathrm{ppm})$ and salicylic acid (100 ppm) resulted in greater values for Total Soluble Salts (TSS), vitamin C, lycopene and carotenoids while, lower values for these parameters were recorded in control. Total acidity was significantly greater in fruits when $\mathrm{GA}_{3}(100$ ppm) was applied. Total acidity was significantly lower in fruits of plants from control.
\end{abstract}

Received | June 01, 2020; Accepted | July 20, 2020; Published | October 08, 2020

*Correspondence | Syed Atif Hasan Naqvi, Department of Plant Pathology, Bahauddin Zakariya University, Multan, Pakistan; Email: atifhasanshah@hotmail.com

Citation | Naz, S., S.A.H. Naqvi, B. Siddique, M.A. Zulfiqar and A. Rehman. 2020. Exogenous application of selected antioxidants and phyto development directors influenced the development, output and biochemical attributes of tomato (Lycopersicum esculentum Mill.). Pakistan Journal of Agricultural Research, 33(4): 789-797.

DOI | http://dx.doi.org/10.17582/journal.pjar/2020/33.5.789.797

Keywords | $\mathrm{GA}_{3}$, Salicylic acid/2, Hydroxybenzoic acid, Ascorbic acid, growth, Yield, Biochemical attributes

\section{Introduction}

$\mathrm{T}$ omato played a vital role in food nutrition due to its main contribution of minerals, vitamins and lycopene viz. ß-carotene and ascorbic acid which are antioxidants and tend to maintain good health (Wilcox et al., 2003). Plant growth regulators have significant role in horticulture to promote growth, development and fruit yield of plants by enhancing fruit setting, fruit number and fruit size. Plant growth regulators played a vital function in maintaining internal plant growth processes by interrelating with major metabolic mechanisms i.e., protein synthesis and nucleic acid metabolism. Application 
of gibberellins and auxin are effectual in enhancing yield attributes and tomato fruit quality (Gemici $e t$ al., 2006). Plant growth regulators may be used as alternatives to enhance crop production. It has been realized globally that PGR's are helpful in improving crop yield. Among PGR's, Gibberellins controlled various developmental processes viz. germination, growth, shoot and internodes elongation, flowering, tuber formation, enzyme production and fruit set in different plant species (Davies, 1995). These PGRs were used widely in tomato to increase yield such as number of fruits, fruit set and fruit size (Serrani et al., 2007; Batlang, 2008). Fruit setting in tomato was improved by the application of Gibberellic acid $\left(\mathrm{GA}_{3}\right)$ at lower quantity reported by Sasaki et al. (2005) and Khan et al. (2006). Alam and Khan (2002) reported that application of Naphthyl acetic acid NAA reduced pre-harvest dropping of fruit in addition to enhance fruit numbers and yield. Improved tomato growth and fruit yield was obtained with the spray of 2, 4-D (5 mg/ 1) (Anwar et al., 2010). GA is one of the important PGRs that might have role to modify plant growth, yield and yield attributes (Rafeekher et al., 2002). Gibberellic acid plays an imperative Partin cell division and elongation and ultimately affecting the plant growth positively (Batlang et al., 2006).

Salicylic acid (SA) is an endogenous plant hormone phenolic in nature are documented to affect the diverse biochemical and physiological processes of plants, regulate the growth and productivity of plants (Hayat et al., 2010), flower induction, thermogenesis, ethylene biosynthesis and nutrient uptake (Hayat and Ahmad, 2007), photosynthesis and increase dry matter production (Fariduddin et al., 2003). It played a diverse role in improving growth of plants such as leaf area of Glycine max and Zea mays (Khan et al., 2003), enhance germination in wheat (Shakirova, 2007). Foliar spraying of salicylic acid (SA) to soya bean increased flower number and pod formation (Kumar et al., 1999). Increased growth attributes, pigments and photosynthetic rate was recorded when salicylic acid was applied on maize (Khodary, 2004). Spraying of salicylic acid to carrot plants also improved growth, enhanced physiological processes and antioxidant activities (Eraslan et al., 2007). Larque and Martin (2007) reported that yields of tomato and cucumber amplified meaning fully with the provision of 2-hydroxybenzoic acid concentrations at lower amounts. This study was therefore carried out to determine suitable doze of antioxidants and phy to development directors that improve tomato quality, output and development of fruit.

\section{Materials and Methods}

Experimentations were pursued at the Agricultural experimental vegetable farm, Bahauddin Zakariya University, Multan, Pakistan during 2014 and 2015. Six weeks old tomato seedlings were transplanted at line to line and herb to herb distance of $1 \mathrm{~m}$ and $0.4 \mathrm{~m}$, correspondingly. All the important cultural operations were performed during experiment. The conducts consist of control (only water spray), two levels of each PDD i.e. $\mathrm{GA}_{3}$ (50 and $100 \mathrm{ppm}$ ), NAA (30 and 60 parts/million) beside with 2, 4-Dichlorophenoxyacetic acid (10 and 20 parts/ million) in addition antioxidants i.e. salicylic acid at one hundred and two hundred parts/million and ascorbic acid at one hundred and two hundred parts/million). The treatments were arranged in a Completely Randomized Block Design (CRBD) with three replications. The experiments stock solutions (1000 ppm) of all PGRs were prepared and diluted in distilled water to prepare these ppm solutions of PGRs and antioxidants. These were sprayed on plants fifteen days after transplanting the seedlings and subsequent sprays were applied three times at fifteen days interval.

\section{Growth and yield attributes}

The height of plants, leaf number per plant and leaf area was measured at the time of picking. Leaf area meter (AM 200, ADC, Taiwan) was used to measure leaf area. Fruit number per plant from each treatment was counted by adding up the fruit number at each picking. Fruit length was measured from each treatment with measuring scale. Fruits fresh and dry weight of individual fruit in each treatment was measured. Weight of fruits per plant at every picking was weighed, and then summed up all the fruits of each picking. Fruit yields per plot and hectare from each treatment were calculated.

\section{Biochemical attributes}

Totally solvable solids (TSS) (Brix $)$ of tomato berry were estimated by means of digital refractometer (At ago PAL-1 Japan) (AOAC, 1970). Total acidity in fruits was measured following the method given by Wills and $\mathrm{Ku}$ (2002). Titrimetric method was used to measure vitamin $\mathrm{C}$ using 2, 6- dichloroindophenol (AOAC, 1970). Fruit lycopene contents were 
determined by using the method (Sadasivan and Manikam, 1992). Carotenoids in fruit pericarp were extracted by $85 \%$ acetone and estimated on spectrophotometer (UV 3000, ORI, Germany) following the method described by Lichtenthaler and Weliburn (1983).

\section{Arithmetical scrutiny}

The outcomes gained were point estimates $\pm \mathrm{SD}$ of three repeats. One-way ANOVA was applied by using MSTAT-C statistical software (version 1.3) (Steel et al., 1996). Duncan's Multiple Range test (DMR-test) was utilized to observe the differences among mean values at 5\% probability level (Duncan, 1952).

\section{Results and Discussion}

\section{Growth attributes}

Phyto-stature: The data on plant stature of tomato as influenced by shoot system provision ofphyto development directors and free-radical huntersare displayed in the Table 1 . Significantly taller (104.37 $\mathrm{cm}$ ) tomato plants were documented with the $\mathrm{GA}_{3}$ provision at 100 parts/million, trailed by salicylic acid with concentration of 200 parts/ million (103.63 $\mathrm{cm})$ and $100 \mathrm{ppm}$ (102.53). However, $\mathrm{GA}_{3}$ at 100 parts/million and 2, hydroxybenzoic acid at 200 parts/million and 100 parts/million appeared alike statistically. While, the minimum plant height $(80.90$ $\mathrm{cm}$ ) was documented using control, which was statistically at face value to $2,4-\mathrm{D}$ at $10 \mathrm{ppm}$.

Number of leaves per plant: There were remarkable variations in leaf number per tomato plant in response to application of various PGRs and antioxidants (Table 1). The maximum leaf number per plant (284.50) was recorded at $100 \mathrm{ppm}$ GA3, which was followed by salicylic acid at $200 \mathrm{ppm}$ (268.50), while the minimum leaf number (108.33) were recorded in the plants from control, which was statistically alike with NAA (30 ppm) and 2,4-Dichlorophenoxyacetic acid (10 parts/million).

Leaf area $\left(\mathbf{m}^{2}\right.$ plant $\left.\mathbf{t}^{-1}\right)$ : Leaf area of tomato was expressively influenced due to provision of various development directors and antioxidants (Table 1). Significantly larger leaf area $\left(48.83 \mathrm{~cm}^{3}\right)$ was observed when shoot spray of 2, hydroxybenzoic acid (200 $\mathrm{ppm})$ was subjected, $\mathrm{GA}_{3}$ at $100 \mathrm{ppm}\left(48.56 \mathrm{~cm}^{3}\right)$ and salicylic acid at $100 \mathrm{ppm}\left(47.33 \mathrm{~cm}^{3}\right)$. These three treatments were statistically at par with each other.
While, spraying of 2,4-D (10 ppm) resulted in lower leaf area $\left(28.23 \mathrm{~cm}^{3}\right)$, which was statistically alike with control and NAA (Table 1).

\section{Yield attributes}

Fruit number per plant: Phyto development directors and antioxidants had substantial effect on number of fruits on individual plant. The maximum fruit number (30.23), (29.50) and (28.90) were seen with the application of $\mathrm{GA}_{3}(100$ parts/million), and 2, Hydroxybenzoic acid (100 and 200 parts/million), correspondingly. Whilst, the minimum fruit number per tomato plant (15.70) found in control (without Phyto development directors and antioxidants), shadowed by 2, 4-Dichlorophenoxyacetic acid with dose 10 parts/million (Table 2).

Fruit length: Length of tomato fruit was remarkably varied due to application various PDDs and antioxidants. It is cleared from Table 2, length of fruit $(4.95 \mathrm{~cm})$ and $(4.90 \mathrm{~cm})$ remarkable increase occur in response to spray of Gibberellic acid (100 parts/ million) and salicylic acid (200 ppm), respectively. While, shorter length $(4.23 \mathrm{~cm})$ of fruits was attained with control.

Individual fruit fresh weight: The specific fruit fresh heaviness $(91.20 \mathrm{~g})$ was significantly increased with the spray of $\mathrm{GA}_{3}$ (100 parts/million), shadowed by 2, Hydroxybenzoic acid (200 parts/million) (90.90 $\mathrm{g})$. Though, lower fresh weight of fruit $(81.40 \mathrm{~g})$ was found in control (Table 2).

Individual fruit dry weight: The foliar spraying of PGRs and antioxidants significantly affected the dry weight of individual fruit. $\mathrm{GA}_{3}$ at $100 \mathrm{ppm}(10.32 \mathrm{~g})$ and salicylic acid at $200 \mathrm{ppm}(10.29 \mathrm{ppm})$ were statistically at par with greater fruit dry mass. Whilst, lower fruit dryness $(9.21 \mathrm{~g})$ was observed with control (Table 2).

Bulk of fruits from individual plant: Individual plant's fruit weight was significantly raised due to exogenous spraying of $\mathrm{GA}_{3}$ (100 parts/million), trailed by2, Hydroxybenzoic acid (200 and 100 parts/ million). While, the minimum weight of fruits per plant was obtained with control (Table 3).

Yield per hectare: Significantly greater tomato yield was obtained with $\mathrm{GA}_{3}$ spray $(100 \mathrm{ppm})$, followed by salicylic acid (200 and 100 ppm). While, lower yield was recorded with control (Table 3). 
Table 1: Comparative efficacy of growth regulators and antioxidants on growth of tomato.

\section{Treatments}

Control (only water spray)

Gibberellic acid $\left(\mathrm{GA}_{3}\right)$

Naphthalene acetic acid (NAA)

2,4-Dichlorophenoxyacetic acid (2,4-D)

Salicylic acid (SA)

Ascorbic acid

\section{Concentration applied}

0 ppm

$50 \mathrm{ppm}$

100 ppm

30 ppm

60 ppm

$10 \mathrm{ppm}$

$20 \mathrm{ppm}$

$100 \mathrm{ppm}$

200 ppm

$100 \mathrm{ppm}$

200 ppm
Plant height (cm) Leaf number

$80.90 \pm 0.30 \mathrm{fg}$

$94.10 \pm 0.70 \mathrm{~b}$

$104.37 \pm 0.70 \mathrm{a}$

$83.37 \pm 0.97 \mathrm{e}$

$88.73 \pm 0.40 \mathrm{c}$

$81.13 \pm 0.55 f$

$88.30 \pm 0.53 \mathrm{c}$

$102.53 \pm 0.68 \mathrm{a}$

$103.63 \pm 0.90 \mathrm{a}$

$85.63 \pm 0.12 \mathrm{de}$

$92.30 \pm 0.80 \mathrm{~b}$
Leaf area $\left(\mathrm{cm}^{3}\right)$

$108.33 \pm 0.57 \mathrm{~h}$

$28.90 \pm 0.36 \mathrm{~g}$

$227.83 \pm 0.28 \mathrm{~d}$

$44.47 \pm 0.25 b$

$284.50 \pm 0.50 \mathrm{a}$

$48.83 \pm 0.35 \mathrm{a}$

$108.83 \pm 0.28 \mathrm{~h}$

$30.90 \pm 0.36 \mathrm{fg}$

$190.33 \pm 0.57 \mathrm{e}$

$40.73 \pm 0.25 \mathrm{c}$

$111.40 \pm 0.52 \mathrm{gh} \quad 28.23 \pm 0.58 \mathrm{~g}$

$183.67 \pm 0.58 \mathrm{f}$

$37.73 \pm 0.28 \mathrm{de}$

$263.33 \pm 0.57 \mathrm{c}$

$47.33 \pm 0.15 \mathrm{a}$

$268.50 \pm 0.50 \mathrm{~b}$

$48.56 \pm 0.12 \mathrm{a}$

$192.67 \pm 0.58 \mathrm{e}$

$36.77 \pm 0.25 \mathrm{e}$

$226.33 \pm 0.57 \mathrm{~d}$

$43.37 \pm 0.66 b$

Data are means of two seasons-Mean values $\pm S D$ of three replications. Dissimilar letters in columns showed remarkable differentiations (p $\leq 0.05$ ) among means of various actions.

Table 2: Comparative efficacy of growth regulators and antioxidants on fruiting of tomato.

\section{Treatments}

Control (only water spray)

Gibberellic acid $\left(\mathrm{GA}_{3}\right)$

Naphthalene acetic acid (NAA)

2,4-Dichlorophenoxyacetic acid (2,4-D)

Salicylic acid (SA)

Ascorbic acid

\section{Concentration Fruit number per Fruit length} applied plant

0 ppm

50 ppm

100 ppm

30 ppm

60 ppm

$10 \mathrm{ppm}$

20 ppm

100 ppm

200 ppm

100 ppm

200 ppm
$15.70 \pm 0.20 \mathrm{e}$

$25.77 \pm 0.25 b c$

$30.23 \pm 0.25 \mathrm{a}$

$16.77 \pm 0.15 \mathrm{de}$

$23.33 \pm 0.20 \mathrm{c}$

$15.88 \pm 0.08 \mathrm{e}$

$23.57 \pm 0.12 \mathrm{c}$

$28.90 \pm 0.40 \mathrm{ab}$

$29.50 \pm 0.72 \mathrm{a}$

$23.40 \pm 0.10 \mathrm{c}$

$24.53 \pm 0.25 \mathrm{c}$ (cm)

$4.23 \pm 0.05 \mathrm{~h}$

$4.29 \pm 0.02 \mathrm{c}$

$4.95 \pm 0.10 \mathrm{a}$

$3.43 \pm 0.05 \mathrm{~g}$

$3.89 \pm 0.05 \mathrm{de}$

$3.60 \pm 0.10 \mathrm{f}$

$3.77 \pm 0.05 \mathrm{e}$

$4.83 \pm 0.05 b$

$4.90 \pm 0.01 \mathrm{ab}$

$3.87 \pm 0.05 \mathrm{e}$

$3.57 \pm 0.15 f$

\section{Specific fruit}

fresh mass (g)

$81.40 \pm 0.10 \mathrm{ef}$

$89.13 \pm 0.72 b$

$91.20 \pm 0.26 \mathrm{a}$

$82.43 \pm 0.15 \mathrm{e}$

$86.47 \pm 0.25 \mathrm{~d}$

$82.30 \pm 0.40 \mathrm{e}$

$86.70 \pm 0.20 \mathrm{~cd}$

$90.10 \pm 0.26 \mathrm{ab}$

$90.90 \pm 0.36 \mathrm{a}$

$87.03 \pm 0.98 \mathrm{c}$

$88.13 \pm 0.72 b c$
Specific fruit dry mass (g)

$9.21 \pm 0.01 \mathrm{f}$

$10.08 \pm 0.08 b$

$10.32 \pm 0.02 \mathrm{a}$

$9.33 \pm 0.01 \mathrm{de}$

$9.79 \pm 0.02 \mathrm{~d}$

$9.32 \pm 0.04 \mathrm{e}$

$9.81 \pm 0.02 \mathrm{~d}$

$10.19 \pm 0.04 \mathrm{ab}$

$10.29 \pm 0.03 \mathrm{a}$

$9.85 \pm 0.11 \mathrm{~cd}$

$10.09 \pm 0.08 b$

Data are means of two seasons- Mean values $\pm S D$ of three repetitions. Dissimilar letters in columns showed substantial differences ( $p \leq 0.05$ ) among means of differentiated actions.

Table 3: Comparative efficacy of growth regulators and antioxidants on yield of tomato.

\section{Treatments}

Control (only water spray)

Gibberellic acid $\left(\mathrm{GA}_{3}\right)$

Naphthalene acetic acid (NAA)

2,4-Dichlorophenoxy acetic acid (2,4-D)

Salicylic acid (SA)

Ascorbic acid

\section{Concentration applied}

0 ppm

$50 \mathrm{ppm}$

100 ppm

$30 \mathrm{ppm}$

$60 \mathrm{ppm}$

$10 \mathrm{ppm}$

$20 \mathrm{ppm}$

$100 \mathrm{ppm}$

200 ppm

$100 \mathrm{ppm}$

$200 \mathrm{ppm}$
Fruits weight per plant (g)

$1274.97 \pm 0.63 \mathrm{~h}$

$2278.66 \pm 0.81 \mathrm{c}$

$2742.94 \pm 0.85 \mathrm{a}$

$1382.12 \pm 0.22 \mathrm{f}$

$2024.86 \pm 0.80 \mathrm{e}$

$1306.12 \pm 0.79 \mathrm{~g}$

$2033.57 \pm 0.89 \mathrm{e}$

$2635.02 \pm 0.62 b$

$2666.70 \pm 0.60 \mathrm{~b}$

$2009.92 \pm 0.15 f$

$2163.09 \pm 0.91 \mathrm{~d}$
Fruit yield (tonnes/ha)

$21.30 \pm 0.73 \mathrm{j}$

$45.49 \pm 0.62 \mathrm{c}$

$55.72 \pm 0.51 \mathrm{a}$

$24.41 \pm 0.67 \mathrm{~h}$

$38.84 \pm 0.86 f g$

$22.162 \pm 0.23 \mathrm{i}$

$37.83 \pm 0.75 \mathrm{~g}$

$53.89 \pm 0.70 \mathrm{~b}$

$54.99 \pm 0.36 \mathrm{ab}$

$38.40 \pm 0.55 \mathrm{fg}$

$41.89 \pm 0.50 \mathrm{e}$

Data are means of two seasons-Mean values $\pm S D$ of three repetitions. Dissimilar letters in columns showed momentous differentiations ( $p \leq$ 0.05) among means of different conducts. 
Table 4: Comparative efficacy of plant growth regulators and antioxidants on biochemical attributes of tomato fruits.

\begin{tabular}{|c|c|c|c|c|c|c|}
\hline Treatments & $\begin{array}{l}\text { Concentra- } \\
\text { tion applied }\end{array}$ & $\begin{array}{l}\text { TSS (mg/g d. } \\
\text { wt) }\end{array}$ & $\begin{array}{l}\text { Total acidity } \\
(\mathrm{mg} / \mathrm{l})\end{array}$ & $\begin{array}{l}\text { Vitamin C } \\
\left(\mathrm{mg} / 100 \mathrm{~cm}^{3}\right)\end{array}$ & Lycopene & $\begin{array}{l}\text { Carotenoids } \\
(\mathrm{mg} / \mathrm{g} \text { d.wt })\end{array}$ \\
\hline Control (only water spray) & $0 \mathrm{ppm}$ & $59.53 \pm 0.65 f g$ & $3884.33 \pm 0.57 \mathrm{a}$ & $235.33 \pm 0.57 f$ & $13.56 \pm 0.05 \mathrm{~g}$ & $0.250 \pm 0.01 \mathrm{f}$ \\
\hline \multirow[t]{2}{*}{ Gibberellic acid $\left(\mathrm{GA}_{3}\right)$} & $50 \mathrm{ppm}$ & $69.40 \pm 0.10 \mathrm{~b}$ & $2955.66 \pm 0.57 c$ & $253.46 \pm 0.45 c$ & $19.03 \pm 0.25 c$ & $0.420 \pm 0.01 \mathrm{c}$ \\
\hline & $100 \mathrm{ppm}$ & $75.23 \pm 0.66 \mathrm{a}$ & $2440.33 \pm 0.58 f$ & $272.50 \pm 0.50 \mathrm{ab}$ & $23.56 \pm 0.20 \mathrm{a}$ & $0.533 \pm 0.005 \mathrm{ab}$ \\
\hline \multirow{2}{*}{$\begin{array}{l}\text { Naphthalene acetic acid } \\
\text { (NAA) }\end{array}$} & 30 ppm & $60.5 \pm 0.81 \mathrm{ef}$ & $3789.17 \pm 0.76 b$ & $240.33 \pm 0.57 \mathrm{e}$ & $13.73 \pm 0.05 \mathrm{~g}$ & $0.256 \pm 0.005 f$ \\
\hline & $60 \mathrm{ppm}$ & $65.46 \pm 0.20 \mathrm{~cd}$ & $2678.16 \pm 0.76 \mathrm{e}$ & $247.83 \pm 0.76 \mathrm{~d}$ & $15.76 \pm 0.15 \mathrm{ef}$ & $0.383 \pm 0.005 \mathrm{~d}$ \\
\hline \multirow{2}{*}{$\begin{array}{l}\text { 2,4-Dichlorophenoxy acetic } \\
\text { acid }(2,4-D)\end{array}$} & $10 \mathrm{ppm}$ & $58.53 \pm 0.65 \mathrm{~g}$ & $2657.33 \pm 0.58 \mathrm{e}$ & $239.66 \pm 0.57 \mathrm{e}$ & $13.53 \pm 0.41 \mathrm{~g}$ & $0.250 \pm 0.010 f$ \\
\hline & $20 \mathrm{ppm}$ & $65.47 \pm 0.82 \mathrm{~cd}$ & $2450.66 \pm 0.57 f$ & $246.10 \pm 0.85 \mathrm{~d}$ & $15.63 \pm 0.23 \mathrm{e}$ & $0.384 \pm 0.011 \mathrm{~d}$ \\
\hline \multirow[t]{2}{*}{ Salicylic acid (SA) } & 100 ppm & $74.56 \pm 0.20 \mathrm{a}$ & $3685.67 \pm 0.57 c$ & $271.16 \pm 0.76 b$ & $22.50 \pm 0.43 b$ & $0.526 \pm 0.005 b$ \\
\hline & 200 ppm & $75.40 \pm 0.10 \mathrm{a}$ & $2448.67 \pm 0.57 f$ & $274.16 \pm 0.76 \mathrm{a}$ & $23.96 \pm 0.80 \mathrm{a}$ & $0.550 \pm 0.01 \mathrm{a}$ \\
\hline \multirow[t]{2}{*}{ Ascorbic acid } & 100 ppm & $66.73 \pm 0.58 \mathrm{~cd}$ & $2964.16 \pm 0.76 c$ & $248.33 \pm 0.57 \mathrm{~cd}$ & $14.63 \pm 0.15 f g$ & $0.370 \pm 0.01 \mathrm{e}$ \\
\hline & $200 \mathrm{ppm}$ & $66.80 \pm 0.95 c$ & $2748.66 \pm 0.57 d$ & $252.93 \pm 0.86 c$ & $17.47 \pm 0.05 \mathrm{~d}$ & $0.433 \pm .005 c$ \\
\hline
\end{tabular}

Data are means of two seasons-Mean Values $\pm S D$ of three repetitions. Dissimilar letters in columns showed considerable differences $(p \leq 0.05)$ among means of different conducts.

\section{Biochemical attributes}

Total soluble solids (TSS): Significant variations were recorded in all the quality attributes of tomato due to application of various growth regulators and antioxidants (Table 4). Provision of 200 parts/million of 2, Hydroxybenzoic acid resulted in greater totally solvable solids, shadowed by $\mathrm{GA}_{3}$ application at 100 parts/million and salicylic acid 100 parts/million. These three concentrations of salicylic acid and $\mathrm{GA}_{3}$ were arithmetically at face value. The minimum figure of TSS was obtained from control.

Total acidity: Significantly greater total acidity was recorded with control (only water spray). While, lower values for total acidity was recorded with $\mathrm{GA}_{3}(100$ parts/million), which was statistically homogeneous with 2, Hydroxybenzoic acid (200 parts/million) and 2,4-D (20 ppm) (Table 4).

Vitamin C: 200 parts/million provision of 2, Hydroxybenzoic acid resulted in greater vitamin $\mathrm{C}$, trailed by spraying of Gibberellic acid $\mathrm{GA}_{3}(100$ parts /million) and salicylic acid (100 ppm). Former two treatments were statistically at par and later two were also statistically alike with each other. While, the minimum value for total acidity was recorded with control (Table 4).

Lycopene (mg/100 goffresh matter): Spray of salicylic acid $(200 \mathrm{ppm})$ and $\mathrm{GA}_{3}(100 \mathrm{ppm})$ resulted in significantly greater value for lycopene. These two treatments were statistically at par with each other. While, the minimum value for lycopene was obtained with control, that was statistically alike with NAA at 30 ppm, 2,4-Dichlorophenoxyacetic acid at 10 parts/ million and ascorbic acid at 100 parts/million (Table 4).

Carotenoids: Remarkably higher carotenoids were documented with the spray of 2, Hydroxybenzoic acid (200 parts/million), down to it withGA (100 parts/million). While least content of carotenoids was recorded with control, followed by 2,4-Dichlorophenoxyacetic acid (10 parts/million) and Naphthyl acetic acid (100 parts/million). These three treatments were statistically homogeneous (Table 4).

Taller plants and leaf number per plant were documented when Gibberellic acid GA (100 parts/ million) and Hydroxybenzoic acid (200 and 100 part/million) was sprayed, The increase in growth attributes might possibly due to that these PGRs accelerated greater cell division, cell enlargement and stem elongation which ultimately resulted in longer tomato plants and greater leaf number. Similar findings for tomato growth were also described by various researchers (E1-Soad et al., 1976; Viradia, 1982; Gabal et al., 1999; Gupta and Gupta, 2000; Rai et al., 2006; Uddain et al., 2009). The ongoing learning was also supported by Akand et al. (2015), who also obtained the longest tomato plants and greater leaf number with the spray of $125 \mathrm{ppm} \mathrm{GA}_{3}$ compared to control one.

Spray of 2, Hydroxybenzoic acid (200, 100 parts/ million) and $\mathrm{GA}_{3}$ (100 parts/million) increased the 
leaf area of tomato. It might probably due to that salicylic acid and PGRs enhanced cell division. It was also previously stated that the spray of salicylic acid (SA) and PGRs tends to promote cell division and cell enlargement (Viradia, 1982; Gabal et al., 1999; Hayat et al., 2005; Uddain et al., 2009). Increased leaf area of sugarcane due to the spray of salicylic acid was also documented by Zhou et al. (1999).

Applied $\mathrm{GA}_{3}$ and 2, Hydroxybenzoic acid resulted in greater fruit number, fruit length, sole fruit's desiccated and non-desiccated weight per plant fruit weight and yield per hectare. It might possibly $\mathrm{GA}_{3}$ application enhanced fruit setting and fruit size when applied at vegetative stage, which ultimately enhance fruit number and fruit weight in tomato. Increased weight and length of fruit of tomato also recorded with the spray of $\mathrm{GA}_{3}$ (Serrani et al., 2007; Verma et al., 2014), which supported the present results. The present outcomes were collaborated with the deductions of Khan et al. (2006) and Akand et al. (2015), who found that $\mathrm{GA}_{3}$ spraying to tomato enhanced the fruit set that tends to increase fruit number and size and ultimately enhance fruit yield. Kaushik et al. (1974) revealed that foliar spraying of PGRs and antioxidants was effectual as it might be contributed to more supply and accumulation of food materials in plants and its efficient mobility in plants resulting in increased growth stimulation, ultimately helped in earlier flower initiation, increased fruit set, rapid fruit development, fruit number, fruit length and weight of fruits which all together enhanced yield. These results are closely related to those of Viradia, 1982; Sharma and Tiwari, 1987; Mehta et al. (1989); Pundir and Yadav (2001); Bhosle et al. (2002) and Patel et al. (2012). Significantly increased tomato growth and yield was also obtained with the spraying of GA3 (Kumar et al., 2014). The present results are in close agreement with Kumar et al. (1999) who documented that the application of salicylic acid resulted in amplified flowering, pod formation and yield of soybean. Similarly, increased growth, produce and produce characteristics of tomato was attained with the spraying of 2, Hydroxybenzoic acid (Stevens et al., 1977). They further proposed that increased fruit yield of tomato due to application of salicylic acid (SA) was associated with the effect of this antioxidant on photosynthetic attributes and water relations of plants. Similarly, enhanced rate of photosynthesis, concentration of carbon dioxide greater water utility efficiency was recorded in Brassica juncea when salicylic acid (SA) was applied externally (Fariduddin et al., 2003).

Exogenous spray of 2, Hydroxybenzoic acid at 200 ppm increased totally solvable solids (TSS), ascorbic acid, lycopene and carotenoids in fruits of Lycopersicum esculentum, which was followed by spraying of $\mathrm{GA}_{3}$ application (100 ppm) and salicylic acid (100 ppm). TSS values were associated with flavor and taste and it was important sign for improvement in fruit quality of tomato. The present outcomes are in close proximity with the discoveries of (Stevens et al., 1977), stated that the 2, Hydroxybenzoic acid application raised TSS values of tomato fruits. This could be related that salicylic acid had effective role in improving membrane permeability, which ultimately facilitated the assimilation, exploitation of mineral nutrients and helped in transport of assimilates. Similarly, TSS values of cowpea were significantly increased with the 2, Hydroxybenzoic acid application as stated by Stevens et al., 1977. Furthermore, 2, hydroxybenzoic acid (SA) usehas a beneficial effect in increasing the TSS values (Abdullahi et al., 2011. The present study was partially related with Gelmesa et al. (2012), Graham and Ballesteros, (2006) and Kumar et al. (2014), they reported that maximum TSS in fruit of tomato was found when $\mathrm{GA}_{3}$ was applied related to parameter of control.

Foliar spray of2, Hydroxybenzoic acid to tomato enhanced the lycopene contents and vitamin $\mathrm{C}$ contents in fruits when compared with control likewise the present study. Kumar et al. (2014) described that greater ascorbic acid of tomato fruits found when $\mathrm{GA}_{3}$ at50 ppm was applied compared to control which was partially supported the present study. Foliar application of $\mathrm{GA}_{3}$ to tomato significantly enhanced fruit lycopene contents of tomato (Khan et al., 2003) which was also related to the present study. Similarly, provision of Gibberellic acid raised the lycopene contents of tomato fruits that were attributed with greater accumulation of phosphorus in leaves and stems (Afaf et al., 2007; Gelmesa et al., 2010). Current findings are in close relation with conclusions of Moharekar et al. (2003), who stated that 2, Hydroxybenzoic acid (SA) played dynamic role to enhance the synthesis of xanthophylls and carotenoids.

Total acidity was significantly increased in fruits of the plants from control and it was observed that antioxidants and PGRs at their higher 
concentrations were not effective in increasing total acidity. Our findings are in relation with the observations of Ouzounidou et al. (2010), who foundedGA $\mathrm{A}_{3}$ unaffected onto acidity of Capsicum fruit which is titratable. Qureshi et al. (2013) confirms the present results concerning the influence ofGA $\mathrm{A}_{3}$ on acidity of strawberries which is titratable. Titratable acidity was also unaffected by 2 , Hydroxybenzoic acid spray (Qureshi et al., 2013).

\section{Conclusions and Recommendations}

From the present study, it is inferred that the foliar spraying of $\mathrm{GA}_{3}$ at $100 \mathrm{ppm}$ or salicylic acid at 200 and $100 \mathrm{ppm}$ can be opted to increase the growth and development, yield and concerned attributes of it. Salicylic acid (SA)/ 2, Hydroxybenzoic acid founded to be an effective plant hormone due to its assorted regulatory/ directory functions in maintaining plant metabolism and influences the photosynthetic attributes, ultimately enhances growth and fruit output of tomato. It might possibly have concluded that the continued enhancement in the studied attributes due to spraying of GA3 (100parts/million) and salicylic acid (200 parts/million) probably leading to greater growth, productivity, TSS, vitamin C, total acidity, lycopene and carotenoids of tomato.

\section{Novelty Statement}

Foliar applications of N.A.A., GA 3 , 2, 4-Dichlorophenoxyacetic acid and antioxidants i.e. Ascorbic acid and 2-hydroxybenzoic acid have a strong effect on the development of fruit bearing and overall growth of the plant with biochemical attributes of Lycopersicum esculentum.

\section{Author's Contribution}

Safina Naz conceived the idea and wrote introduction and methodology, statistical analysis was performed by Syed Atif Hasan Naqvi and Abdur Rehman and overall management of the article was done by Bushra Siddique and Muhammad Asif Zulfiqar.

\section{Conflict of interest}

The authors have declared no conflict of interest

\section{References}

Abdullahi, M., M. Jafarpour and H. Zeinali. 2011.
Effect of various salicylic acid concentrations on growth of Aloe vera L. Int.J. Agric. Sci., 1(5): 311-313.

Afaf, T.M.K., A.M. Abd El-hameid and N.H.M. El-Greadly. 2007. A comparison study on the effect of some treatments on earliness, yield and quality of globe artichoke (Cynara scolymus L.). Res. J. Agric. Biol. Sci., 3: 695-700.

Akand, M.H., H.E.M.K. Mazed, M.A. Islam, M. Pulok, S.N. Chowdhury and J.F. Moonmoon. 2015. Growth and yield of tomato (Lycopersiconesculentum Mill.) as influenced by different level of gibberellic acid application. Int. J. Appl. Res., 1(3): 71-74

Alam, S.M. and M.A. Khan. 2002. Fruit yield of tomato as affected by NAA spray. Asian J. Plant Sci., 1(1): 24. https://doi.org/10.3923/ ajps.2002.24.24

Anwar, W., T. Aziz, F. Naveed and S.T. Sahi. 2010. Short Communication. Foliar applied 2, 4-dichlorophenoxy acetic acid improved tomato growth and yield. Soil Environ., 29(1): 77- 81.

AOAC, 1970. Official methods of analysis of the association of the analytical chemists. 17 ed., Washigton. D.C.

Batlang, U., 2008. Benzyladenine plus gibberellins $(\mathrm{GA} 4+7)$ increase fruit size and yield in greenhouse-grown hot pepper (Capsicum annuиm L.). J. Biol. Sci., 8(3): 659-662. https:// doi.org/10.3923/jbs.2008.659.662

Batlang, V., V.E. Emongor and F. PuleMeulenburg. 2006. Effect of benzyladenine and gibberellic acid on yield and yield components of cucumber (Cucumis sativus L. cv. tempo). J. Agron.,5(3): 418-423.https://doi.org/10.3923/ ja.2006.418.423

Bhosle, A.B., S.B. Khorbhade, P.B. Sanap and M.J. Gorad. 2002. Effect of plant hormones on growth and yield of summer tomato (Lycopersiconesculentum Mill.). Orissa J. Hortic., 30(2): 63-65.

Davies, P.J., 1995. Plant hormones, physiology, biochemistry and molecular biology. Kluwer Acad. Publ., Dordrecht. https://doi. org/10.1007/978-94-011-0473-9

Duncan, D.B., 1952. Multiple Range and Multiple F-test. Biometrics. 11: 42. https://doi. org/10.2307/3001478

El-Soad, I.A.A., A.F. Omran and N.I. Ashour. 1976. Stimulatory effects of 2, 4-D on growth and yield of tomato. Egypt. J. Hortic., 3(2): 
$149-155$

Eraslan, F., A. Inal, A. Gunes and M. Alpaslan. 2007. Impact of exogenous salicylic acid on growth, antioxidant activity and physiology of carrot plants subjected to combined salinity and boron toxicity. Sci. Hortic., 113: 120-128. https://doi.org/10.1016/j.scienta.2007.03.012

Fariduddin, Q. S. Hayat and A. Ahmad. 2003. Salicylic acid influences net photosynthetic rate, carboxylation efficiency, nitrate reductase activity and seed yield in Brassica juncea. Photosynthetica, 41: 281-284. https://doi. org/10.1023/B:PHOT.0000011962.05991.6c

Gabal, G.M., G. Oben and R. Garcell. 1999. Effect of GA on morph physiological characters and yield of kidney beans (Phaseiolusvalgaris). J. Agron. Crop Sci., 160(2): 91-101.

Gelmesa, D., B. Abebie and L. Desalegn. 2010. Effects of Gibberellic acid and 2,4-dichlorophenoxyacetic acid spray on fruit yield and quality of tomato (Lycopersicon esculentum Mill.). J. Plant Breed. Crop Sci., 2(10): 316-324. https://doi.org/10.4314/star. v2i3.98720

Gelmesa, D., B. Abebie and L. Desalegn. 2012. Regulation of tomato (Lycopersicon esculentum Mill.) fruit setting and earliness by gibberellic acid and 2,4 dichlorophenoxy acetic acid application. Afr. J. Biotechnol., 11(51): 1120011206. https://doi.org/10.5897/AJB11.2928

Gemici, M., B. Türkyilmaz and K. Tan. 2006. Effect of 2,4-D and 4-CPA on yield and quality of the tomato, Lycopersicon esculentum Mill. J. Food Sci., 29: 24-32.

Graham, H.D. and M. Ballesteros. 2006. Effect of plant growth regulators on plant nutrients. J. Food Sci. 45(3): 502-505. https://doi. org/10.1111/j.1365-2621.1980.tb04086.x

Gupta, P.K. and A.K. Gupta. 2000. Efficacy of plant growth regulators (IAA and NAA) and micronutrient mixture on growth, flowering, fruiting and shelf life of tomato (Lycopersicon esculentum Mill.). Bioved., 11: 25-29.

Hayat, S. and A. Ahmad. 2007. Salicylic acid: A plant hormone, Springer Dortrecht, The Netherlands. https://doi.org/10.1007/1-40205184-0

Hayat, S., Q. Fariduddin, B. Ali and A. Ahmad. 2005. Effect of salicylic acid on growth and enzyme activities of wheat seedlings. Acta Agronomica Hungarica, 53: 433-437. https://
doi.org/10.1556/AAgr.53.2005.4.9

Hayat, Q., S. Hayat, M. Irfan and A. Ahmad. 2010. Effect of exogenous salicylic acid under changing environment: A review. Environ. Exp. Bot., 68: 14-25. https://doi.org/10.1016/j. envexpbot.2009.08.005

Kaushik, M.P., J.K. Sharma and I. Singh. 1974. Effect of alpha naphthalene acetic acid, gibberellic acid, kinetin and morphactin of yield of tomato. Plant Sci., 6: 51-53.

Khan, W., B. Prithviraj and D.L. Smith. 2003. Photosynthetic responses of corn and soybean to foliar application of salicylates. J. Plant Physiol., 160: 485-492. https://doi.org/10.1078/01761617-00865

Khan, M.M.A., A.C. Gautam, F. Mohammad, M.H. Siddiqui, M. Naeem and M.N. Khan. 2006. Effect of gibberellic acid spray on performance of tomato. Turk. J. Biol., 30: 11-16.

Khodary, S.F.A., 2004. Effect of salicylic acid on the growth, photosynthesis and carbohydrate metabolism in the salt stressed maize plants. Int. J. Agric. Biol., 6: 5-8.

Kumar, P., S.D. Dube and V.S. Chauhan. 1999. Effect of salicylic acid on growth, development and some biochemical aspects of soybean (Glycine max L. Merrill). Int. J. Plant Physiol., 4: 327-330.

Kumar,A.,T.K. Biswas, N. Singh and E.P.Lal.2014. Effect of gibberellic acid on growth, quality and yield of tomato (Lycopersiconesculentum Mill.). IOSR J. Agric. Vet. Sci., 7(7): 28-30. https:// doi.org/10.9790/2380-07742830

Larque-Saavedra, A. and R. Martin-Mex. 2007. Effect of salicylic acid on the bio-productivity of plants. In: Hayat S and Ahmad A. (Eds). Salicylic acid. A plant hormone. Springer Publishers. Dordrecht. The Netherlands.

Lichtenthaler, H.K. and W.R. Weliburn. 1983. Determination of total carotenoids and chlorophylls $\mathrm{a}$ and $\mathrm{b}$ of leaf extracts in different solvents. Biochem. Soc. Trans., 11: 591-592. https://doi.org/10.1042/bst0110591

Mehta, A.K., R.P. Singh and G. Lal. 1989. Effect of concentration and methods of application of $2,4-\mathrm{D}$ on yield, fruit quality and seed quality of tomato. Vegetable Sci., 16(1): 1-8.

Moharekar, S.T., S.D.Lokhande, T.Hara, R.Tanaka, A. Tanaka and P.D. Chavan. 2003. Effect of salicylic acid onclorophyll and carotenoid contents of wheat and moong caryopsis. 
Photosynthetica, 41: 315-317. https://doi. org/10.1023/B:PHOT.0000011970.62172.15

Ouzounidou, G., I. Ilias, A. Giannakoula and P. Papadopoulou. 2010. Comparative study on the effects of various plant growth regulators on growth, quality and physiology of capsicum annum L. Pak. J. Bot., 42(2): 805-814.

Patel, J.S., H.H. Sitapara and K.A. Patel. 2012. Influence of plant growth regulators on growth, yield and quality of tomato and brinjal. Int. J. For. Crop Improv., 3(2): 116-118.

Pundir, J.P.S. and P.K. Yadav. 2001. Note on effect of GA3 NAA and 2, 4-D on growth, yield and quality of tomato var. Punjab Chuhara. Curr. Agric., 25: 137-138. https://doi.org/10.6090/ jarq. 39.135

Qureshi, K.M., S. Chughati, U.S. Qureshi, N.A. Abbasi. 2013. Impact of exogenous application of salt and growth regulators on growth and yield of strawberry. Pak. J. Bot., 45(4): 11791185.

Rafeekher, M., S.A. Nair, P.N. Sorte, G.P. Hatwal and P.M. Chandhan. 2002. Effect of growth regulators on growth and yield of summer cucumber. J. Soils Crops, 12(1): 108-110.

Rai, N., D.S. Yadav, K.K. Patel, R.K. Yadav, B.S. Asati and T. Chaudey. 2006. Effect of plant growth regulators on growth, yield and quality of tomato (Lycopersicon esculentum Mill). Vegetable Sci., 33(2): 180-182.

Sadasivam, S. and A. Manickam. 1992. Biochemical methods for agricultural sciences. Wiley Eastern Limited. New Dehli.

Sasaki, H., T. Yano and A. Yamasaki. 2005. Reduction of high temperature inhibition in tomato fruit set by plant growth regulators. Jarq-Japan Agric. Res. Q. 39: 135-138.

Serrani, J.C., M. Fos, A. Atare's and J.L. Garc1'aMartı'nez. 2007. Effect of gibberellin and auxin on parthenocarpic fruit growth induction in the cr Micro-Tom of tomato. J. Plant Growth Regul., 26: 211-221. https://doi.org/10.1007/ s00344-007-9014-7

Shakirova, F.M., 2007. Role of hormonal system in the manisfestation of growth promoting and anti-stress action of salicylic acid. In: Hayat $\mathrm{S}$ and Ahmad A. (Eds). Salicylic Acid. A Plant
Hormone. Springer. Dordrecht. Netherlands.

Sharma, N.K. and R.S. Tiwari. 1987. Effect of 2, 4-D application on tomato cv. Pusa ruby. South Indian J. Hortic., 35(5): 390-392.

Sittu, G.A. and J.A. Adelekha. 1999. Effect of gibberellic acid on the growth and development of tomato (Lycopersicon esculentum Mill.) cultivar 158-163. Global J. Pure Appl. Sci., 5(1): 27-30.

Steel, R., J.Torrie and D.A. Dickey. 1996. Principles and procedures of statistics: A biometrical approach (3rd Ed.). McGraw Hill Book Co., New York, pp. 666.

Stevens, M.A., A.A. Kader, M.A. Albright-Holten and M. Algazi. 1977. Effect of fruit ripeness when picked on flavor and composition in fresh market tomatoes. J. Am. Soc. Hortic. Sci., 102: 724-731.

Uddain, J., K.M.A. Hossain, M.G. Mostafa and M.J. Rahman. 2009. Effect of different plant growth regulators on growth and yield of tomato. Int. J. Sustainable Agric., 1(3): 58-63.

Verma, P.P.S., M.L. Meena and S.K. Meena. 2014. Influence of plant growth regulators on growth, flowering and quality of tomato (LycopersiconEsculentumMill), cv. H-86. Indian J. Hill Farm., 27(2): 19-22.

Viradia, R.R., 1982. Effect of growth regulators on growth, yield and quality of tomato cv. Pusa ruby. M. Sc. (Ag.) thesis, Gujarat Agric. Univ., S.K. Nagar, Gujarat, India.

Wilcox, J., G. Catignani and C. Lazarus. 2003. Tomatoes and cardiovascular health. Crit. Rev. Food Sci. Nutr., 43(1): 1-18. https://doi. org/10.1080/10408690390826437

Wills, R.B.H. and V.V. Ku. 2002. The use of $1-\mathrm{MCP}$ to extend the time toripen of green tomatoes and postharvest life of ripe tomatoes. Postharvest Biol. Technol. 26, 85-90. https:// doi.org/10.1016/S0925-5214(01)00201-0

Zhou, X.M., A.F. Mackeuzie, C.A. Madramootoo and D.L.J. Smith. 1999. Effects of some injected plant growth regulators with or without sucrose on grain production biomass and photosynthetic activity of field-grown corn plants. Agro Crop Sci., 183: 103-110. https:// doi.org/10.1046/j.1439-037x.1999.00331.x 